Jean-Charles Szurek

\title{
Prawda historyczna i fikcja literacka - debata na temat Jana Karskiego we Francji
}

Byłoby nadużyciem umieszczanie książki Yannicka Haenela o Janie Karskim¹, będącej niedawno przyczyną ostrej polemiki we Francji, w ramach kiczu, fałszu, braku autentyzmu. Książka zawiera jednak specyficzne przesłanie, które można kwestionować ze względu na pewnego rodzaju wybieg: fikcja literacka przejmuje władzę nad prawdą historyczną, w istotny sposób modyfikując przedstawione fakty. Przyznając relacji fikcyjnej większe znaczenie niż historycznej, Yannick Haenel poruszył nowe zagadnienia w rozważaniach o eksterminacji Żydów.

Wiemy, jakie były etapy docierania do świadomości faktu Zagłady Żydów. Wydarzenia, od dwudziestu lat nazywane Szoa (odkąd film Shoah Claude'a Lanzmanna nadał im tę nazwę), a od dawna Holokaustem, zostały początkowo wpisane w kontekst, w którym nie różnicowało się ofiar. Zapewne tuż po wojnie, w dominującej traumatycznej wizji, przypisywano ruchowi oporu - i lewicowemu, i prawicowemu - szczególne miejsce. Miejsce „deportowanych ze względów rasowych”, jak mówiło się wówczas we Francji, zepchnięto w polityce upamiętniania daleko za deportowanych kombatantów, choć tych „rasowych” deportacji było najwięcej i to ich ofiary najczęściej mordowano. Ówczesny antyfaszyzm zgodnie z ideologią stanowił ekspresję narodów napadniętych przez nazistów - Żydzi byli częścią tych narodów i nie widziano powodu, żeby myśleć o nich jako o odrębnej grupie. Antyfaszyzm był powszechnie wyznawaną ideologią, która we Francji doprowadziła do zawarcia paktu gaullistowsko-komunistycznego. W zsowietyzowanej Europie antyfaszyzm szybko powiązano z budową socjalizmu (najlepsze antidotum na faszyzm to socjalizm, głosiła komunistyczna propaganda). Dopiero u schyłku lat siedemdziesiątych, kiedy do publicznej świadomości zaczął docierać rozmiar ludobójstwa II wojny światowej, zmieniła się także perspektywa: cenne opracowanie Raula Hilberga ${ }^{2}$ stopniowo stawało się podstawowym źródłem wiedzy na temat eksterminacji Żydów. W ślad za nim pojawiło się wiele innych książek, filmów (jak na przykład Holocaust czy już wspomniany Shoah Claude’a Lanzmanna). Warto podkreślić, że książka Hilberga została wydana we Francji dopiero w roku 1988.

${ }^{1}$ Y. Haenel, Jan Karski. Roman, Paris 2009. Wszystkie cytaty w niniejszym tekście pochodzą z francuskich wydań cytowanych publikacji.

${ }^{2}$ R. Hilberg, The destruction of the European Jews, New York 1961. 
Zarówno prace na temat wyjątkowego wymiaru Szoa, jak i dyskusje na ich temat (zwłaszcza o książkach będących odpowiedzią na podkreślanie tej wyjątkowości: Tzvetana Todorova ${ }^{3}$, Paula Ricoeura ${ }^{4}$, Jean-Michela Chaumonta ${ }^{5}$ czy Normana Finkelsteina ${ }^{6}$ ) przyczyniły się do sakralizacji Zagłady Żydów - albo poprzez tworzenie ahistorycznego dystansu, albo poprzez banalizację. Owa sakralizacja jest zrozumiała i wynika z niesłychanego charakteru zbrodni. Nigdy wcześniej nie zdarzyło się przecież podobne połączenie planowania i przemysłowej techniki, tak metodyczny mord na dzieciach czy wywózka obywateli państw europejskich do miejsc kaźni. Są to trzy główne cechy tego procederu. Do tego jeszcze obnażanie ofiar, przede wszystkim kobiet, ich - co niesłychane - rejestrowanie na niezliczonych zdjęciach robionych przez niemieckich żołnierzy ${ }^{7}$, a także fakt, że ofiary były Żydami, co musiało się wiązać z chrześcijańskim antyjudaizmem i antysemityzmem. Wszystko to sprawia, że owo wydarzenie, mimo licznych wyjaśnień, pozostaje nieprzeniknione. I dlatego od dwudziestu lat wciąż skłania do nowych poszukiwań i badań, głównie historycznych. Są jednak i tacy, którzy po prostu wybrali drogę rojeń, co przynosiło zadziwiające skutki społeczne. Tak było w przypadku sprawy Binjamina Wilkomirskiego, alias Brunona Grosjeana, szwajcarskiego autora, który wymyślił historię swojej „deportacji” do obozu w Majdanku w wieku czterech lat. Opisał ją jako rzeczywistą i czytelnicy mu uwierzyli, poczynając od członków dwóch jury - a więc specjalistów - którzy przyznali mu zaszczytne nagrody: we Francji Prix de la Fondation de la Mémoire de la Shoah (Nagrodę Fundacji Pamięci Szoa) oraz National Jewish Book Award w Stanach Zjednoczonych pod koniec lat dziewięćdziesiątych. Ta zmyślona relacja miała wszelkie cechy autentycznych wspomnień. Fikcja wyglądała na rzeczywistość, a najdziwniejsze jest, że zdołała tak mocno przekonać wytrawnych specjalistów, wśród których byli także deportowani Żydzi, że dali się oszukać. Ta powieść nie została nazwana „powieścią”

W przeciwieństwie do zbrodni komunistycznych, Szoa wciąż stanowi źródło zdumiewająco bogatej twórczości literackiej, psychoanalitycznej i, oczywiście, historycznej. Spośród dzieł literackich trzeba wspomnieć o powieści Jonathana Lit-

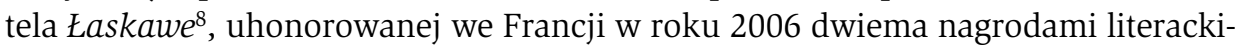
mi. Autor na dziewięciuset stronach opisuje w niej eksterminację Żydów widzianą oczyma esesmana.

${ }^{3}$ T. Todorov, Les abus de la mémoire, Paris 1995.

${ }^{4}$ P. Ricoeur, La mémoire, l'histoire, l’oubli, Paris 2000, wyd. polskie: Pamięć, historia, zapomnienie, przeł. J. Margański, Kraków 2006.

${ }^{5}$ J.-M. Chaumont, La concurrence des victimes, Paris 1997.

${ }^{6}$ N. Finkelstein, The Holocaust Industry. Reflections on the Exploitation of Jewish Suffering, London 2000, wyd. polskie: Przedsiębiorstwo holokaust, przeł. M. Szymański, Warszawa 2001.

7 Ten aspekt został doskonale przeanalizowany przez D. Goldhagena, Hitler's Willing Executioners. Ordinary Germans and the Holocaust, New York 1996, wyd. polskie: Gorliwi kaci Hitlera. Zwyczajni Niemcy i Holocaust, przeł. W. Horabik, Warszawa 1999.

${ }^{8}$ J. Littel, Łaskawe, przeł. M. Kamińska-Maurugeon, Kraków 2008. 
Właśnie na tle tak różnorodnej twórczości związanej z Szoa postrzegać należy polemikę, którą wywołała książka Yannicka Haenela. A polemika ta ma wiele aspektów. Książka niezaprzeczalnie podobała się czytelnikom. Jej prawdziwa w istocie teza - o czym każdy może się sam przekonać - dotyczy kwestii obojętności, Żydzi zaś są tu tylko pretekstem. Główny bohater to Jan Karski, o którym autor dowiedział się z filmu Shoah Claude’a Lanzmanna. Haenel był wtedy nauczycielem w liceum i ze wzruszeniem - jak sam mówi - przedstawiał uczniom przesłanie Karskiego oraz dzielił się swoimi odczuciami. Tak zrodził się pomysł powieści, której struktura wydaje się osobliwa. Składają się na nią trzy części: pierwsza relacjonuje to, co Karski powiedział Lanzmannowi w Shoah, druga stanowi resumé książki Karskiego9", trzecia zaś jest czystą fikcją. W tej części Karski-Haenel, który mówi w pierwszej osobie, staje się Haenelem-Karskim, oddalając się od historycznej postaci polskiego kuriera. I głównie ta trzecia część, ze względu na historyczno-polityczne przesłanie autora, wywołała dyskusję.

Otóż kolejna wyrazista teza tej książki, wyrażona przez Haenela-Karskiego, mówi o zbrodniczej i umyślnej nieodpowiedzialności wobec Holokaustu jako o najlepiej przestrzeganym pakcie zawartym przez aliantów. „W roku 1945 nie było zwycięzców”, pisze Haenel, „byli tylko wspólnicy i kłamcy”10 . „Wiedzieli Anglicy, wiedzieli Amerykanie. Wiedząc o wszystkim, nie starali się powstrzymać eksterminacji Żydów w Europie. Być może według nich po prostu nie należało jej powstrzymywać i być może nie należało dać europejskim Żydom szansy ocalenia"11.

Poddając się zrozumiałemu uniesieniu, Haenel-Karski w niezbyt oględnych słowach atakuje prezydenta Roosevelta, który jest przedstawiony jako lubieżny Poncjusz Piłat. Proces norymberski - prowadzi swą myśl Haenel - zręcznie sterowany przez Amerykanów, był tylko grą, mającą pozwolić na „przemilczenie kwestii współudziału aliantów w eksterminacji europejskich Żydów”12.

Mówi się, że fikcja literacka ma swoje prawa. W tym przypadku opiera się ona na pewnym prawdopodobieństwie, obraca się w sferze możliwości. Jednak całość jest historycznie fałszywa.

$* * *$

Po pierwsze, nieprawdą jest, że alianci zawarli pakt milczenia. Przedmiotem procesu norymberskiego nie było wymierzenie kary za Holokaust jako taki, ponieważ wówczas tę kwestię postrzegano inaczej - choć Rafał Lemkin użył pojęcia ludobójstwa już w 1944 r. Gdyby jednak uznać, że Haenel ma rację, to i tak trudno by było przypisać aliantom zbrodnie popełnione przez Niemców.

${ }^{9}$ J. Karski, Story of a Secret State, Boston 1944; pierwsze polskie wydanie: Tajne państwo opowieść o polskim Podziemiu, Warszawa 1999.

${ }^{10}$ Y. Haenel, op. cit., s. 115.

${ }^{11}$ Ibidem, s. 116.

${ }^{12}$ Ibidem, s. 166. 
Podczas procesu w Norymberdze Otto Ohlendorf, dowódca Einsatzgruppe D, nie ukrywając prawdy, opisywał masowe rozstrzeliwania dokonywane na ludności żydowskiej, w tym także na dzieciach. Inny oskarżony, SS-Hauptsturmführer Dieter Wisliceny, szczegółowo mówił o działaniach sekcji IV-A-4b Reichssicherheitshauptamt (RSHA), której powierzono „kwestię żydowską”, a także o Adolfie Eichmannie, który w związku z tym przedstawił mu założenia Endlösung i wyjawił, że celem jest eksterminacja wszystkich Żydów. Zeznania Wisliceny’ego wykorzystano podczas procesu Eichmanna w roku 1961. Podczas procesu nazistowskich dowódców Rudolf Höss, były komendant Auschwitz, w swoich zeznaniach także mówił o komorach gazowych i o procedurze uśmiercania Żydów. O ich prześladowania oskarżonych było wielu spośród sądzonych w Norymberdze, także ci najwyżsi rangą (Göring, von Ribbentrop, Frank itd.) ${ }^{13}$. Nie było zatem zmowy milczenia w tej sprawie. Nawet imputowanie zbrodni katyńskiej Niemcom, co próbowali zrobić Rosjanie, zostało przez aliantów odrzucone.

Oskarżenie o obojętność, stawiane przez Haenela aliantom - zwłaszcza Amerykanom i Anglikom - wynika z potrzeby uzyskania odpowiedzi na wiele razy powtarzane pytanie: skoro alianci wiedzieli - a przecież byli informowani przez rząd londyński, przez Jana Karskiego i innych - to dlaczego nie zapobiegli tej zbrodni? Nie zrobili nic, powtarza autor, ponieważ nie leżało to w ich interesie: „Ani Anglicy, ani Amerykanie nie chcieli przyjść z pomocą europejskim Żydom, bo bali się, że będą musieli ich przyjąć”" ${ }^{4}$. Twierdzi także, że ich ślepota miała również inne przyczyny: bezwład biurokracji, niechęć rozgłoszenia, żeby „nie wzburzyć opinii publicznej”15, anglo-amerykański antysemityzm. I dla Yannicka Haenela staje się jasne, że alianci do samego końca nie chcieli „zbombardować komór gazowych w Auschwitz ani prowadzących do nich linii kolejowych, tłumacząc wszystko tym, że najważniejsze są cele militarne"16.W ten sposób garść prawdopodobnych lub rzeczywistych racji splata się w powieści z rozprawą historyczną. Nawet jeśli prawdą jest, że Stany Zjednoczone odmówiły na początku wojny przyjęcia Żydów (przykład: historia statku „Saint Louis”), nawet jeżeli istotnie opinię publiczną nastawiano tak, żeby skłonna była wspierać wysiłek zbrojny, choćby kosztem wątpliwości moralnych, i jeśli nawet Roosevelt nie chciał dopuścić, by zarzucano mu uleganie wpływom „żydowskiego lobby”, to wszystkie te argumenty razem wzięte nie tworzą wyjaśnienia historycznego.

Tymczasem w tamtym okresie - powtórzmy to raz jeszcze - nie istniały warunki, aby można było pojąć rzeczywistą naturę ludobójczego przedsięwzięcia. Dotyczy to części rozmówców Karskiego, zwłaszcza Feliksa Frankfurtera, sędziego Sądu Najwyższego Stanów Zjednoczonych, Żyda. Amerykański prezydent zobowiązał Karskiego, by się z nim spotkał (podobnie jak z wieloma innymi przed-

\footnotetext{
${ }^{13}$ Por. A. Wieviorka, Le procès de Nuremberg, Paris 2006, s. 190.

${ }^{14}$ Y. Haenel, op. cit., s. 129.

15 Ibidem, s. 130.

${ }^{16}$ Ibidem, s. 145.
} 
stawicielami amerykańskich elit). Karski szczegółowo przedstawił mu sytuację Żydów w Polsce i przekazał wiadomości, które przywiózł. Frankfurter słuchał w milczeniu, a w końcu powiedział: „Młody człowieku, wiem, że przybywa pan z piekła i że wkrótce pan tam wróci. Podziwiam pana. Nie jestem już młody, jestem sędzią, znam naturę człowieka, wiem, że ludzie tacy jak pan i ja muszą być całkowicie uczciwi. Nie mówię, że pan kłamie, ja mówię, że panu nie wierzę"17. Karski powtórzył te słowa Claude’owi Lanzmannowi, gdy ten w roku 1978 kręcił film Shoah i Lanzmann wykorzystał je w filmie Le rapport Karski ${ }^{18}$, który w odpowiedzi na książkę Haenela wyświetlono we Francji w marcu 2010 r., a przywołano także w „Les Temps Modernes”19.

Przypomnijmy, że musiało upłynąć czterdzieści lat, aby świat poznał wyjątkowy charakter eksterminacji Żydów w jego pełnym wymiarze, przedtem znanym tylko w kręgach rodzinnych lub wspólnotowych. Trzeba było ciężkiej pracy pamięci, jak się to obecnie nazywa (w porównaniu z „obowiązkiem pamięci”), żeby władze publiczne przyznały jej to miejsce, które dziś zajmuje - uznanie przez Jacques’a Chiraca zbrodni Vichy przeciwko Żydom, powstanie odrębnych muzeów poświęconych Holokaustowi (Waszyngton, Berlin), zmiany w Mémorial de la Shoah (Paryż). We Francji dzieła takie jak film Shoah Claude'a Lanzmanna czy Déportation et génocide ${ }^{20}$ Annette Wieviorki są wyrazem tego historiograficznego zwrotu w sferze pamięci i polityki. W roku 1945 taka percepcja nie istniała, ponieważ wiedzy o Holokauście nie towarzyszyła świadomość, którą dziś mamy. Walter Laqueur jako jeden z pierwszych wskazał powody istnienia zasadniczej różnicy między czasem uzyskania informacji a czasem reakcji na nią, także ze strony środowisk żydowskich. Warto przypomnieć niektóre z nich.

W początkowym okresie wojny wielu Żydów interpretowało postępowanie Niemców przez pryzmat I wojny światowej. Do nich należał Adam Czerniaków, przewodniczący Rady Żydowskiej w Warszawie, który aż do swojej samobójczej śmierci 23 lipca 1942 r. usiłował „wytrzymać” niemiecką politykę. Żądanie wydania dzieci z getta sprawiło, że zrozumiał, jak bardzo się myli. Po akcjach Einsatzgruppen, pisze Laqueur, „większość żydowskiej starszyzny z Europy Wschodniej nie uświadamiała sobie jeszcze, że te mordy to tylko wstęp do systematycznej eksterminacji”21. Jak więc na przykład amerykańscy Żydzi mogli zrozumieć, że chodzi o eksterminację? Z pewnością krążyły pogłoski, ale te były sprzeczne, bo Niemcy z jednej strony zabijali Żydów, z drugiej jednak - potrzebowali ich do pracy. Odsyłamy czytelnika do zakończenia książki Waltera Laqueura, który przedstawia pewne podstawowe socjologiczne mechanizmy niemożności uświadomienia sobie

${ }^{17}$ J. Karski, Franklin Delano Roosevelt, un leader du monde, „Les Temps Modernes” nr 657/2010, janvier-mars 2010, s. 18.

${ }^{18}$ C. Lanzmann, Le raport Karski, 2010.

19 „Les Temps Modernes”, op. cit.

${ }^{20}$ A. Wieviorka, Déportation et génocide, Paris 1992.

${ }^{21}$ W. Laqueur, Le terrifiant secret. La „solution finale” et l'information étouffée, Paris 1981, s. 239. 
tragedii Żydów. W latach osiemdziesiątych ten problem - możliwości ocalenia Żydów i bombardowania szlaku kolejowego do Auschwitz - stał się tematem wielu badań i poszukiwań. O znanych swego czasu książkach The abandonment of the Jews Davida S. Wymana czy Politics of rescue Henry'ego Feingolda Lanzmann pisze słusznie: „Wszystko tam było prawdą, poza proporcją i czasem, niewypowiedzianą pełnią rzeczywistości, konfiguracją faktu i rzeczy niemożliwych"22. Innymi słowy, nie ma odpowiedzi na pytania, których sobie człowiek nie stawia. Mówiąc słowami Raymonda Arona: „Komory gazowe, mord istot ludzkich na skalę przemysłową... nie, przyznam, że sobie tego nie wyobrażałem, ponieważ nie mógłbym sobie czegoś takiego wyobrazić, nie wiedziałem o tym"23.

Obojętność świata i milczenie aliantów to niejedyne problemy poruszane przez Yannicka Haenela. Na pierwsze miejsce zdecydowanie jednak wysuwa się „zbrodnia Zachodu”. „Interesuje mnie” - mówi w wywiadzie dla „Libération” - „nie Szoa, ale zbrodnia Zachodu, ślepota aliantów na eksterminację, ślepota zorganizowana. Jednym z najśmielszych stwierdzeń Karskiego [Karskiego z powieści - J.-Ch. Sz.] jest nazwanie Norymbergi również operacją wybielania. Na żadnym etapie procesu Stany Zjednoczone nie poruszają kwestii odpowiedzialności Zachodu. Poza tym pozwalają, żeby ZSRR podawało zbrodnię katyńską za dzieło nazistów. Z tych zbrodni miał się narodzić tak zwany wolny świat. Jesteśmy spadkobiercami tej konstelacji kłamstw, tego braku elementarnej przyzwoitości, który sprawia, że od roku 1945 fundamenty Europy są przegniłe"24.

Dlaczego rzeczywiście nie skupić się na „zbrodni Zachodu”? Tylko - jakiej zbrodni? Modny obecnie swoisty esencjalizm zakłada, że fundamenty zachodnich demokracji zostały wzniesione na owej ontologicznej zbrodni, którą jest eksterminacja Żydów. Brnąc w absurd, Haenel dołącza do innego francuskiego autora, Jean-Claude’a Milnera ${ }^{25}$. Zapomina o kompromisach angloamerykańskich wobec Stalina, które doprowadziły do powstania obozu socjalistycznego, a zwłaszcza Polski takiej, jakiej chciała tylko garstka komunistów (a i to nie na pewno...). Zapomina o innych istotnych aspektach II wojny światowej: liczbie poległych Rosjan i innych narodowości ZSRR, zaangażowaniu Ameryki, oporze Anglii. Zamiast tego Haenel-Karski mówi tylko o złej woli Zachodu wobec Szoa.

Może to sprawa pokolenia? Związek Radziecki zniknął, wraz z nim odszedł system komunistyczny. Pozostała rozpasana Ameryka, która wysyła swoje wojska w różne strony świata i rządzi na swój sposób. Pozostała także nienawiść - często

${ }^{22}$ C. Lanzmann, Jan Karski de Yannick Haenel: un faux roman [Jan Karski Yannicka Haenela: zafałszowana powieść], „Les Temps Modernes”, nr 657/2010, janvier-mars 2010, s. 8.

${ }^{23}$ R. Aron, Mémoires. 50 ans de réflexion politique, Paris 1983, s. 242.

24 „Libération”, 22 X 2009.

${ }^{25}$ J.-C. Milner, Les penchants criminels de l'Europe démocratique, Paris 2003. 
podejrzana - której obiektem stała się Ameryka. W tekście Haenela znajdujemy kilka zdecydowanie antykomunistycznych zdań, ale kwestie komunizmu i zła, które wyrządził sowiecki system, nie są tu poruszane. Wiążąc zbrodniczą obojętność wobec eksterminacji z podwalinami demokracji po roku 1945 i podając się za spadkobiercę wolnego świata bez systemu wartości, być może Haenel chce pokazać, że poszukuje tego rodzaju rozumienia i postawy, dla których Ameryka stanowi łatwy i jedyny w swoim rodzaju cel wszelkiej krytyki.

$$
* * *
$$

Zaskakuje także polski wymiar książki Haenela. Owszem, może ona dać satysfakcję tym, których raniła prawda ujawniana w badaniach dotyczących relacji polsko-żydowskich w czasie wojny (a zwłaszcza prawda o zbrodni w Jedwabnem), ale jej przesłanie historyczno-polityczne przenosi nas sześćdziesiąt lat wstecz. Cytaty mówią same za siebie: „[Alianci] starali się za wszelką cenę zniesławić Polskę, przedstawiając ją jako kraj antysemicki. To odium dla dobra ich własnych krajów trzeba było na kogoś zrzucić, żeby zapewnić sobie poczucie oczyszczenia z winy, choć to właśnie oni w ten czy inny sposób kolaborowali z nazistami” [...]. „Chociaż Polacy nie byli odpowiedzialni za eksterminację Żydów, zaczęto ich postrzegać jako katów”. „Potępiając pasywną postawę Polaków wobec eksterminacji, zapomina się, że Polska była okupowana przez nazistów i stalinowców [...], zatem żaden Polak nie miał możliwości działania ${ }^{26 "}$.

Polska, Polska męczeńska, jako jedyna pośród narodów, wychodzi z wojny chwalebnie, a w tej książce, w której eksterminacja Żydów jest kluczowym tematem, nie ma nawet wzmianki ani o szmalcownikach, ani o granatowej policji, ani o zbrodniach popełnionych przez Polaków przeciwko Żydom, ani o polskim antysemityzmie, ani o pogromach w Jedwabnem i Kielcach, ani o wierszu Miłosza Campo di Fiori opisującym karuzelę przed płonącym warszawskim gettem. Nie mówi się tu również o Żegocie ani o Sprawiedliwych. Czemu żądać od Haenela, by przywoływał z pewnością nieznane mu słowa Jerzego Brauna, ostatniego Delegata Rządu w roku 1945, w których stwierdził, że Polacy zajęli miejsce Żydów i że takie są prawa ekonomii? (Dokładnie brzmi to tak: „Na wsi i w małych miastach nie ma dziś miejsca dla Żydów. Przez sześć minionych lat powstał (nareszcie!) trzeci stan polski, którego wcześniej nie było. Całkowicie przejął handel na prowincji, dostawy, pośrednictwo, miejscową wytwórczość [...] i cały drobny przemysł") 27 .

${ }^{26}$ Y. Haenel, op. cit , s. 120, 152 i 181.

${ }^{27}$ Cyt. za: J.T. Gross, Fear. Anti-Semitism in Poland after Auschwitz: An Essay in Historical Interpretation, New York 2008, s. 18, wyd. polskie: Strach. Antysemityzm w Polsce tuż po wojnie. Historia moralnej zapaści, Kraków 2008. 
Cóż jednak z tego, że obraz Polski został wyidealizowany, że Karski Haenela jest zupełnie inny niż prawdziwy Karski, że Roosevelt został przedstawiony jako człowiek niezbyt sympatyczny... Fikcja literacka może sobie pozwolić na wszystko, w przeciwieństwie do nauk społecznych, które muszą żmudnie zbierać dowody, żeby na nich oprzeć dyskurs naukowy. I nic nie pomoże walka spadkobierców Karskiego, którzy protestują przeciwko przekłamaniom, nic nie pomoże walka Lanzmanna, który poczuł się zmuszony do pokazania tego, co powiedział mu Jan Karski. Reguły gry są tu inne.

Fikcja zawsze niesie te wyobrażenia o historii, które zajęły miejsce materiałów historycznych, albo opiera się na nich, ułatwiając zrozumienie wydarzeń. Powieść Jonathana Littella na swój sposób pozwala wczuć się w świat morderców z SS i przybliżyć dramat eksterminacji Żydów, ukazując mało znane aspekty tych zjawisk. Dlaczego jednak Jan Karski Haenela wzbudził tak żywą polemikę, skoro inną francuską powieść, również „paryską”, ale z pewnością bardziej finezyjną w swej historycznej warstwie, Les Sentinelles Brunona Tessarecha, ukazującą tę samą postać w tym samym czasie, spotkało milczenie krytyki i opinii publicznej ${ }^{28}$ ?

Książka Yannicka Haenela wzbudziła gwałtowną reakcję Claude’a Lanzmanna: w imię prawdy historycznej w swym filmie Raport Karskiego pokazał Karskiego z krwi i kości, zdolnego przeciwstawić się Haenelowi-Karskiemu. Niektórzy widzą w tym ataku obronę „własnego pola”, ale nie w tym rzecz. Haenel, tworząc fikcyjnego Karskiego, fałszywego świadka, sam siebie czyni świadkiem. Świadkiem świadka. Mówi to jasno na kartach swej książki, cytując - nieściśle - znane zdanie Paula Celana: „Nikt nie świadczy za świadka”. I dodaje: „Kwestia zakazanych relacji między fikcją a Shoah staje się moim zdaniem niezwykle ważna na początku XXI wieku. Ostatni świadkowie nie żyją lub wkrótce umrą. Jeżeli historia tego przekazu nas przerośnie, a zatem zacznie nas nękać, pisarze będą zmuszeni odpowiedzieć fikcją na natrętne pytania"29. Czy trzeba wypaczać prawdę historyczną, żeby nowy - ostatni świadek mógł złożyć świadectwo? Prawdziwy świadek, Jan Karski, w rzeczywistości nazywający się Jan Kozielewski, przemówił. Pozostawił dość śladów, żebyśmy wiedzieli, co myślał o prezydencie Roosevelcie („Do dziś uważam”, napisał krótko przed śmiercią, „że Roosevelt był największym prezydentem Stanów Zjednoczonych, największym, ponieważ służył całej ludzkości”) ${ }^{30}$. Świadek świadka, Lanzmann, sfilmował i nagrał Karskiego, sam Lanzmann był uczestnikiem i świadkiem wojny. Jakie jeszcze świadectwo może przekazać Haenel-Karski?

$\mathrm{W}$ istocie rzeczy broń, jaką jest fikcja, służy tym razem do usunięcia z pola historii jej aktorów. Podważenie słów Haenelowego świadka staje się głównym powodem reakcji prawdziwego świadka, jakim jest Lanzmann. Prawdopodobnie wca-

\footnotetext{
${ }^{28}$ B. Tessarech, Les sentinelles, Paris 2009.

29 „Liberation”, op. cit.

${ }^{30}$ J. Karski, Widziałem, opr. M. Cichy, „Gazeta Wyborcza”, 2-3 X 1999.
} 
le by nie doszło do tej polemiki, wskazującej i zapowiadającej nowe zagadnienia, gdyby postaci powieści były całkowicie fikcyjne. Być może Yannick Haenel żałuje niebezpiecznych igraszek $\mathrm{z}$ historią.

Powołanie ahistorycznego i antyhistorycznego świadka XXI wieku ociera się o nową formę kiczu. Nie ma wątpliwości, że zjawisko to będzie się nasilać. Skutki takich działań są niebanalne, mogą mieć poważne konsekwencje społeczne. Pamiętamy chyba wszyscy deportowanego do Auschwitz więźnia, Żyda, który podczas obchodów 65. rocznicy wyzwolenia obozu protestował przeciwko bezczynności państw demokratycznych podczas wojny. Może tak właśnie myślał w roku 1945, ale może uległ wpływom historyczno-fikcyjnych rozważań w roku 2010? Na swój sposób zastosował tzw. teoremat Thomasa: „Jeśli ludzie uważają pewne rzeczy za realne, to są one realne w swoich konsekwencjach"31.

Tłumaczenie z francuskiego: Krystyna Szeżyńska-Maćkowiak

${ }^{31}$ William Isaac Thomas (1863-1947), socjolog amerykański, jeden z twórców amerykańskiej socjologii oraz psychologii społecznej. 